\title{
Business Motivation Model for Information System Architecture Development Support
}

\author{
Malgorzata PANKOWSKA \\ University of Economics in Katowice, Katowice, Poland
}

pank@ue.katowice.pl

Received date:4 August 2020; Accepted date: 2 January 2021; published date: 19 January 2021

Academic Editor: Aleksandra Sus

Copyright (C) 2021. Malgorzata PANKOWSKA. Distributed under Creative Commons Attribution 4.0 International CC-BY 4.0

\begin{abstract}
Since the beginning of business management, optimization of enterprise's performance has been recognized as its main objective. However, a suitable motivation model had to be implemented to achieve that goal. This paper aims to present discussion on Object Management Group (OMG) Business Motivation Model (BMM) in theory and in practice. This model is confronted with ArchiMate model and Influence Diagram. The discussed models expressed motivation comparably. Finally, SME Accountancy Bureau case study is presented to support conclusions. The main finding is that Business Motivation analysis supports information system pragmatics considerations as well as its strategy and vision development.
\end{abstract}

Keywords: ArchiMate, Influence Diagram, Business Motivation Model, Accountancy Bureau.

\section{Introduction}

While business modelling does not provide business value per se, it serves as the backbone for many information system development projects, and as such, can be considered a valuable discipline. In general, business models support communication among stakeholders, and aid their training and learning, persuasiveness and business situation analysis, compliance management, software requirements analysis, and knowledge management and reuse
(Bridgeland and Zahavi, 2009). Business models are developed to present different organizational elements, e.g., business goals, organizational structure, business processes and rules. A model is always a certain abstract view of fragmented reality and as such is accepted as valid if it meets all the necessary constraints.

The main focus of this paper is Business Motivation Model (BMM) (OMG, 2015), which describes what a business is going to accomplish. This model is considered in a business context, including business

Cite this Article as: Malgorzata PANKOWSKA (2021)," Business Motivation Model for Information System Architecture Development Support", Journal of Software \& Systems Development, Vol. 2021 (2021), Article ID 668927, DOI: 10.5171/2021.668927 
environment, strategy, stakeholders, resources, principles and assessments. The paper consists of four parts. The first part contains discussions on motivation of individuals and the whole business organizations. Next part focuses on motivation in business analysis and enterprise architecture (EA) frameworks, in ArchiMate model (The Open Group, 2019), and in Influence Diagram (ID) (Hall, 2010). The third part includes literature review on the Object Management Group (OMG) BMM. This article summarizes the twelve years of business motivation modelling experiences, taking into account the publications in prominent repositories of research papers. Finally, a case study of small and medium enterprise (SME) accountancy bureau is discussed and its business motivation models are presented.

\section{Individual vs. Business Motivation}

Generally, people perceive motivation in a positive aspect. Motivation is assumed as vital for social organization development and internal cooperation of its members. The factors, which encourage people to work intensively and creatively, are personal achievements, recognition, advancement, money and power. The need of power is the desire to have impact on other people, to be influential and recognizable, remembered, and to control others. Beyond that, motivation is defined as a mechanism, which influences people to reach organizational or community goals. The concept of motivation is particularly related to the business context and it includes the impact on work behaviour of the environmental factors, as well as business unit capacity, capability and competencies of individual employees (Gaque et al. 2014). The most popular motivation theories are as follow:

- Maslow's Need Hierarchy, which orders the priorities, i.e., physiological needs, safety and security, associations with others, receiving acknowledgement from others, and self-actualisation needs;

- McClelland's Needs Theory, emphasizing the value of personal achievements pushing people to goals despite difficulties, and low rewards;
- Herzberg's Motivator-Hygiene Theory, according to which the achievements, recognition, the job itself, responsibility and advancement opportunities are encouraging people to huge efforts. Herzberg perceived institutional politics, the management methods, supervision, payments, relationships at work, and work conditions as demoralizing factors (Badubi, 2017);

- Vroom Expectancy Theory, which explains that motivation is a product of Valence (i.e., how much an individual wants a reward), Expectancy (i.e., probability that the effort will result in successful performance), and Instrumentality (i.e., estimation that performance will result in receiving the reward).

Business units' motivations concern business strategy, market, stakeholders, current and future economic situation in the enterprise location. Each business unit formulates a hierarchy of business motives. They need the stimulants to stay in market, survive or develop, maximize benefits for the owners and for other stakeholders. There are similar questions concerning motivations of business information systems development and the questions are just as important for system analysts, developers, and users. Business organizations choose one of the following strategies, i.e., aggressiveness, proactiveness, leadership, defensiveness, riskiness, market niche, low costs, or elimination of competitors (Bhattacharya, 2018). Business motivations result from these strategies and simultaneously they also play a role in creating business strategy, particularly business strategic goals and information processing strategic goals.

\section{Motivation in Enterprise Architecture Frameworks}

The Basic Motivation Model by Rheinberg (2008) explains human behaviour as a result of the current motivation. Motivation emerges from an interaction between personal values, goals, and needs, and the perceived potential incentives in a 
current situation. For example, analyses of e-business user's behaviour and motivations are useful for business forecasts formulation. Therefore, business analysts should ask:

- What personal motives drive users in online business to engage?

- How do the personal motives interact with incentives provided in online business?

- In what type of motivation do they result and what kind of engagement is achieved by what type of motivation?

In these questions, answers concern customers' behaviour, but beyond that, a similar set of questions can be formulated for business organizations. Business motivation is discussed and presented in enterprise architecture (EA) frameworks. The term "enterprise" is identified with a company, business organization or governmental institution. According to Robins, an enterprise is considered as a "consciously coordinated social entity, with a relatively identifiable boundary that functions on a relatively continuous basis to achieve a common goal" (Hoogervorst, 2009). The enterprise architecture is defined as a strategic information asset base, which defines the business mission, the information and technology necessary to perform the mission, the processes for implementing new technologies in response to the changing mission needs (Stenzel, 2007). For an enterprise, architectural framework as a conceptual structure related to a certain system type consists of areas of concern and a necessary and sufficient set of design domains. There are many frameworks that support the EA modelling and development, but only some of them (e.g., Zachman Framework, ZF, The Open Group Architecture Framework, TOGAF) consider the issue of motivation for architecture development. The ZF defines a basic structure for organizing business architecture through dimensions such as data, function, network, people, time, and motivation (Zachman, 2010). Zachman proposes the ontology for the creation of EA through negotiations among several actors. The ZF presents various views and dimensions of the enterprise architecture in a matrix form. It includes the following levels (i.e., rows): Scope (contextual, planner view), Enterprise Model (conceptual, owner view), System Model (logical, designer view), Technology Model (physical, builder model), Detailed Representation (out-of-context, subcontractor view), and Functioning Enterprise (user view). The lower the row, the greater the degree of detail of the level represented. The ZF model works with six aspects of the EA (i.e., columns): Data (what), Function (how), Network (where), People (who), Time (when), Motivation (why). All the views create a complete picture of the enterprise. The question "why" is asked at each level to explain the motivations of enterprise to develop the EA. This reveals the enterprise goals, business plan, and business rules.

Beyond enterprise architecture framework, business motivation issue is also included in business guidelines, i.e., BABOK, Business Analysis Body of Knowledge (BABOK, Guide 3, 2015), EABOK, and Enterprise Architecture Body of Knowledge (EABOK, 2004). Although BABOK primary goal is to define the profession of business analyst and provide a set of commonly accepted practices, this guide emphasizes the meaning of company's reputation value and employee morale. Therefore, these can be considered as motives of business and information system development. The EABOK presents the idea of drivers, which are stimulants for business and architecture development. The same concept is also included in the Federal Enterprise Architecture Framework (FEAF) (FEAF, 2012) and in ArchiMate language (The Open Group, 2020). In EABOK, the drivers are factors, conditions, resources, and other forces significantly impacting the organization and stimulating change. Although drivers are de facto outside the control of EA practices, the influence is important. The TOGAF model comprises three core layers, i.e., Business, Application, and Technology. They are supplemented by the Motivation

Malgorzata PANKOWSKA (2021), Journal of Software \& Systems Development,

DOI: $10.5171 / 2021.668927$ 
layer extension. Elements of this layer enable modelling the strategy and motivation underlying an enterprise architecture. The Motivation extension in ArchiMate, the TOGAF language, is applied to support the Business Requirements Management, Preliminary and Architecture Vision phases' realization in the TOGAF architecture modelling process.

A key element of ArchiMate Motivation layer is the "stakeholder" that represents an individual or an organization interested in the EA modelling. By definition, customers, business partners, business and application architects, or legislative authorities are stakeholders. Each stakeholder is motivated, as they enjoyed and are challenged by cooperation on the EA development. Their intrinsic motivations can be as follow: culture, personal values, organizational goals, belief system, fairness issues, but extrinsic motivations include group's norms, values, principles, reward and penalty system, recognition, market position, organizational leadership, or group belief. Another key element in ArchiMate Motivation layer is the "goal", which represents some end that a stakeholder wants to achieve. The end is to represent anything a stakeholder may desire, such as a state of affairs, business value or real effect. Typical examples cover revenue increase, service time reduction, or online service duration. However, discussion about these issues needs to be extended. In the context of the EA modelling, a business organization should ask itself the questions: What information do we owe to people with whom we work, and on whom we depend? In what form? In what time frame? What information do we need ourselves? From whom? For EA development, the strategic information modelling needs to consider the purposes of information processing for business decisions. Therefore, the question of "Why" and the justification of information processing are important. Information system analysist should seek answers to the following:
- Why is information necessary to competing in the business today and in the future?

- What priorities for information use and management are appropriate?

- How should managers implement their strategic priorities and achieve improved business performance through people, information, and ICT?

- When and why will the users be satisfied?

The user-customer loyalty is visible in buying behaviour and in communication channel preference for each customer. The satisfaction is visible in repurchasing, revisiting or aftersales questioning.

\section{Literature Review on BMM}

The OMG Business Motivation Model (BMM) (OMG, 2015) contains a set of built-in concepts that define elements of business plan, and answer the question "Why" enterprise architecture is to be developed. They are associated in a structure which is technology-neutral. The BMM combines the enterprise goals, strategies and motivations. As usual in the model development process, the BMM identifies fundamental concepts essential for business functioning and the relationships among them. The proposed $\mathrm{BMM}$ is to be interpretable by software developers, to communicate with managers, to illustrate the most important issues. A business motivation model describes what a business is going to accomplish, i.e., goals, named here the Ends. The model should explain how the business organization intends to accomplish the goals, what opportunities and threats there are to the business and what the business organization's strengths and weaknesses are. These concepts are included in the Assessments. The Means address how to achieve the Ends and comprise concepts like Organization Units, Business Processes, and Business Rules. There is still the open question of what the fourth element of BMM is, i.e., the Influencers. In this paper, influencers are identified with motivators, incentives, stimulus, or drivers, as it is in the ArchiMate language. In this paper, 
tendencies of selected economic phenomena are treated as Influencers. Assuming that motivation refers to reasons upon which one acts, the literature distinguishes between intrinsic and extrinsic motives. For example, intrinsic business motives include the pursue of profit, but they may also involve social responsibility and moral obligations. As regards extrinsic motivations, business managers are stimulated by competitors, customers, or governmental regulations.

This study outline is presented in Figure 1. The numbers of searching results are summarized in Figure 2. The rudimentary reviews were done using the following databases: Association for Information Systems Electronic Library, IEEE Xplore Digital Library, SAGE journals, Science
Direct, Emerald Insight, Scopus, and Web of Science.

According to the suggestions on the systematic literature review (SLR) process, firstly, taking into account the mentioned above repositories, the phrase "Business Motivation Model" was searched. However, the number of received results was very high, due to the word "Motivation" appearing in various contexts different from the OMG BMM. Moreover, the use of the "BMM" acronym for search did not yield desired results, because it also has other extensions, different from business motivation model. Therefore, further searching was conducted via the search string "Business" AND "Motivation" AND "Model" included in the paper title.

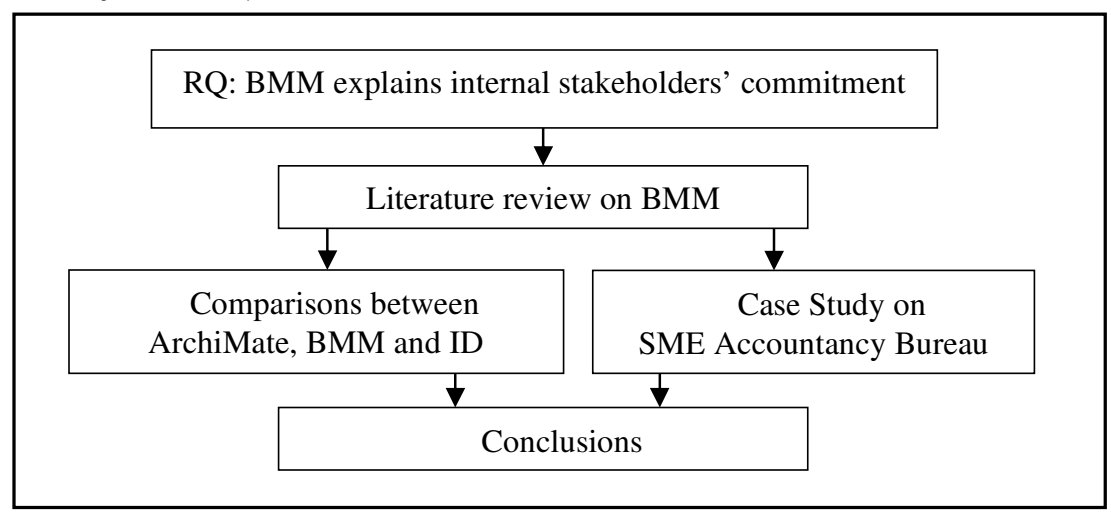

Fig. 1: This Study Structure

Malgorzata PANKOWSKA (2021), Journal of Software \& Systems Development, 


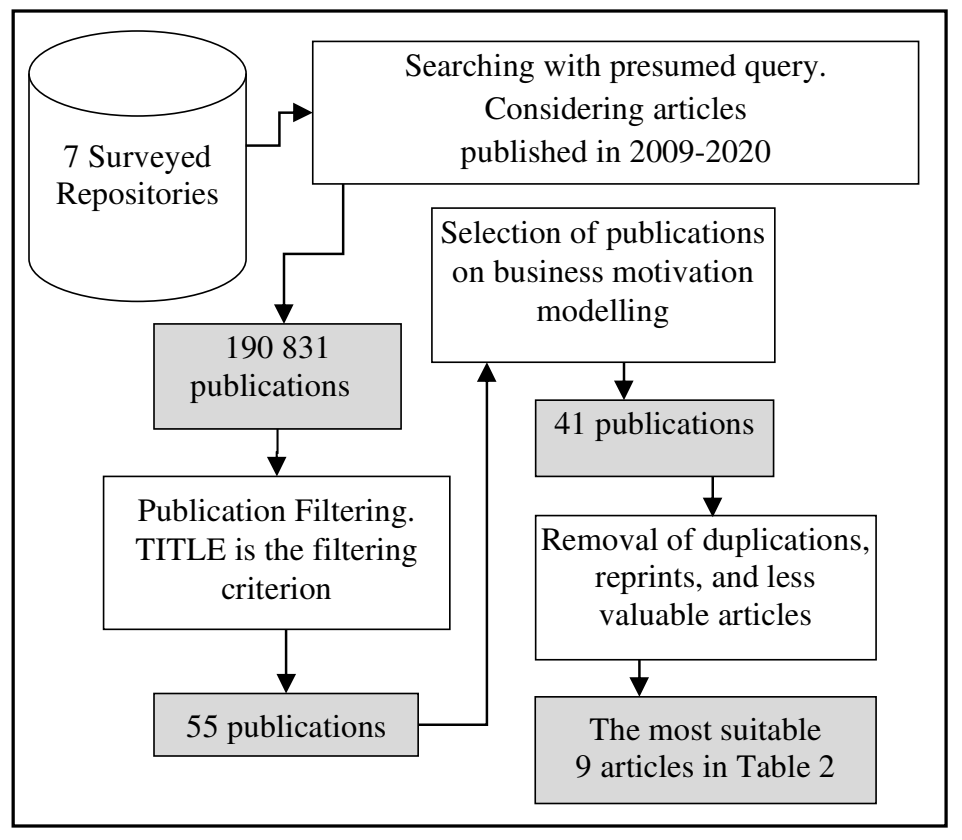

Fig. 2: Repository Searching Results

Table 1 summarized different research approaches and findings concerning the BMM characteristics and domains of usage. Regrettably, there are no papers, which strictly answer questions on the BMM for e-business system architecture development. Although the BMM is considered as the most appropriate for motivation analysis, there are also other techniques and notations, which should be taken into account. Table 2 is about a comparison among ArchiMate, BMM and ID notation aspect. Generally, the influence diagrams are considered as probabilistic graphical models that are particularly suitable to deal with uncertainty as well as with incomplete and imprecise information. The influence diagram (ID) is a visual representation of a decision problem dependent on business functions, determinants, uncertain chances, and business values (Hall, 2010). In this paper, the ID decision reasons are considered as business motives. Business organization has got material and financial resources which are by rules well defined, described and maintained. Business functions have also deterministic character. Business objectives and values are criteria that are expected to be maximized. Constraints on business design and modelling are assumed to be decisions. Business rules, regulations, principles are treated as deterministic reasons.

Table 1: Findings on BMM application in Representative Research (RR)

\begin{tabular}{|l|l|l|}
\hline No & RR & Findings \\
\hline 1 & $\begin{array}{l}\text { Cui and } \\
\text { Paige, 2012 }\end{array}$ & $\begin{array}{l}\text { Proposal of a framework that integrates the development of } \\
\text { motivation and requirements model at the business, product, } \\
\text { system, and software levels. Authors focus on links between the } \\
\text { OMG standardized BMM and Systems Modelling Language } \\
\text { (Sims). }\end{array}$ \\
\hline 2 & $\begin{array}{l}\text { Hinkelmann } \\
\text { and } \\
\text { Pasquini, }\end{array}$ & $\begin{array}{l}\text { Authors conclude that current motivation model languages are } \\
\text { mainly designed to model business strategy, and they do not } \\
\text { give the opportunity to distinguish business view elements and }\end{array}$ \\
\hline
\end{tabular}

Malgorzata PANKOWSKA (2021), Journal of Software \& Systems Development, 


\begin{tabular}{|c|c|c|}
\hline & 2014 & $\begin{array}{l}\text { IT view elements. Authors propose a modelling technique to } \\
\text { improve transparency of the dependencies between business } \\
\text { and IT elements. }\end{array}$ \\
\hline 3 & $\begin{array}{l}\text { Suri et al., } \\
2017\end{array}$ & $\begin{array}{l}\text { Authors provide a model-based approach for creating and } \\
\text { communicating business strategies and bridging the gap } \\
\text { between the business strategies and operational processes } \\
\text { using BMM model and BPMN notation. They simulate processes } \\
\text { to check KPIs to different strategies. }\end{array}$ \\
\hline 4 & $\begin{array}{l}\text { Roubtsova, } \\
2012\end{array}$ & $\begin{array}{l}\text { Author presents how Protocol Modelling semantics can be used } \\
\text { both for business process modelling and motivation modelling. } \\
\text { Author argues that OMG predicts that BPMN will be merged } \\
\text { with the BMM. }\end{array}$ \\
\hline 5 & $\begin{array}{l}\text { Vicente et al., } \\
2014\end{array}$ & $\begin{array}{l}\text { Authors define a specific EA to design organizations according } \\
\text { to ITIL's best practices to perform ITSM. They aim to establish } \\
\text { architecture's motivation model and the ITIL BMM }\end{array}$ \\
\hline 6 & $\begin{array}{l}\text { Lu et al., } \\
2011\end{array}$ & $\begin{array}{l}\text { Authors extend WS-Policy4MASC language that specifies the } \\
\text { BMM concepts for modelling business event. }\end{array}$ \\
\hline 7 & $\begin{array}{l}\text { Berkem, } \\
2008\end{array}$ & $\begin{array}{l}\text { Author links business vision, goals, strategies, tactics and } \\
\text { business rules according to BMM for Service Oriented } \\
\text { Architecture (SOA) specification. }\end{array}$ \\
\hline 8 & $\begin{array}{l}\text { Tonisson } \\
\text { and } \\
\text { Matulevicius } \\
\text {, } 2016\end{array}$ & $\begin{array}{l}\text { Authors apply the semiotic quality framework to compare } \\
\text { quality of the BMM and i* modelling language. }\end{array}$ \\
\hline 9 & $\begin{array}{l}\text { Feglar et al., } \\
2006\end{array}$ & $\begin{array}{l}\text { Authors modify the BMM, so instead of SWOT analysis, they } \\
\text { propose an ANP (Analytic Network Process) based BOCR } \\
\text { (Benefit-Opportunity-Cost-Risk) analysis. }\end{array}$ \\
\hline
\end{tabular}

Table 2: Similar constructs in ArchiMate, BMM and Influence Diagram

\begin{tabular}{|l|l|l|}
\hline ArchiMate & $\begin{array}{l}\text { Business Motivation } \\
\text { Model }\end{array}$ & Influence Diagram \\
\hline $\begin{array}{l}\text { Stakeholder: role of } \\
\text { individual, team or } \\
\text { organization }\end{array}$ & Organizational Unit & \\
\hline $\begin{array}{l}\text { Motive: Driver, condition } \\
\text { that stimulates an } \\
\text { organization to define its } \\
\text { goals }\end{array}$ & $\begin{array}{l}\text { Motive: Influencer, cause } \\
\text { of change }\end{array}$ & $\begin{array}{l}\text { Motive: } \\
\text { Uncertain reason, event, } \\
\text { condition, a chance variable } \\
\text { which cannot be controlled } \\
\text { directly }\end{array}$ \\
\hline
\end{tabular}

Table 2: Similar constructs in ArchiMate, BMM and Influence Diagram (continued)

\begin{tabular}{|c|c|c|}
\hline ArchiMate & \begin{tabular}{|l} 
Business \\
Model
\end{tabular} & Influence Diagram \\
\hline $\begin{array}{l}\text { Assessment: outcome of } \\
\text { SWOT analysis }\end{array}$ & $\begin{array}{l}\text { Assessment: based on } \\
\text { SWOT analysis, but also } \\
\text { potential impact, like risk } \\
\text { or potential reward }\end{array}$ & \\
\hline Goal: achievable end state & $\begin{array}{l}\text { Vision, Goal: desired result } \\
\text { Objective: step on the way } \\
\text { towards the Goal }\end{array}$ & \\
\hline Outcome: end result & $\begin{array}{l}\text { Ends: what an entity } \\
\text { wants to be }\end{array}$ & $\begin{array}{l}\text { Decision: choice, status, } \\
\text { stakeholder has a power to } \\
\text { control it }\end{array}$ \\
\hline $\begin{array}{l}\text { Principle: qualitative } \\
\text { statement of intent }\end{array}$ & $\begin{array}{l}\text { Directives: Business Rules, } \\
\text { Business Policies }\end{array}$ & Deterministic reasons: rules \\
\hline
\end{tabular}

Malgorzata PANKOWSKA (2021), Journal of Software \& Systems Development, 


\begin{tabular}{|l|l|l|}
\hline $\begin{array}{l}\text { Constraints: restriction on } \\
\text { the way in which system is } \\
\text { realized }\end{array}$ & $\begin{array}{l}\text { lecision on business design } \\
\text { constraints }\end{array}$ \\
\hline $\begin{array}{l}\text { Meaning: knowledge in a } \\
\text { particular context }\end{array}$ & & $\begin{array}{l}\text { Value: measure of satisfaction } \\
\text { with possible outcomes }\end{array}$ \\
\hline $\begin{array}{l}\text { Value: utility, measure of } \\
\text { satisfaction }\end{array}$ & $\begin{array}{l}\text { Material, } \\
\text { Facility }\end{array}$ & $\begin{array}{l}\text { Mission, Assets, Means: } \\
\text { resources to achieve Ends }\end{array}$ \\
\hline Service, Function, Process & $\begin{array}{l}\text { Course of Actions: } \\
\text { Strategies, Tactics, Process }\end{array}$ & Function of quantities \\
\hline
\end{tabular}

\section{SME Accountancy Bureau as Case Study}

The enterprise architecture model is assumed to help business organizations to specify business requirements and transform them into system requirements to ensure the ICT is functioning in a costeffective, flexible and reliable way. Modelling system architecture can be interpreted as modelling the structures of processes, information, application components and ICT parts. Taking into account Chandler's idea that "structure follows strategy", business analysis for information system development should begin with the strategy, mission, and vision formulation. However, Chandler (1962) argues that organizational structure is necessary for strategy realization, particularly for production volume expansion, geographic dispersion and vertical integration. The business structure modelling is derived from principles that are based on the empirical deduction of observed behaviours or practices. Similarly to system requirements, principles define intended properties of the enterprise architecture (Stair and Reynolds, 2010). Business principles and the EA development principles are formulated not only in scientific research, but also in practice. They are the laws and observations of nature underlying the artefacts. Business analysis is defined as a set of activities that support discovery and creation of business and system architecture principles. The business analysis is an empirical process that is realized by defining the needs and recommending solutions that provide value to stakeholders.
In the presented case study, the business analysis was realized at SME accountancy bureau. The selected business organization exists since 2000 and its offer is directed to micro, small and medium enterprises, which want to reliably realize their business. The SME enterprises employ fewer than 250 people. Generally, they focus on their core functions and use outsourcing for non-critical activities. Accountancy services, offered by the bureau, are highly customised in accordance with the client business organization profile. The accountancy bureau supports their customers in bookkeeping, taxpaying and insurance. It is responsible for bills and accounting documentation, and reconciliation. The accountancy services offered by the bureau include trading account books, books of income statements and expenditures, tax cards, payments and social insurance. The bureau provides advisory services on how to begin and decommission a business, as well as account books controls and auditing, tax payment review, financial analysis and reports elaboration. Mostly, the services are realized offline, however, the accountancy bureau needs e-business information system to present actual offers, forms of documents, information on prices and promotions, and current legal acts. This business organization's structure is a stable view of the entire enterprise. Taking into account the SWOT (strengths, weaknesses, opportunities and threats) analysis for the accountancy bureau (Figure 3), this business unit's strategy is defined as market penetration and proactiveness. This organization aims to increase its revenue using its existing offers, i.e., accountancy services in existing

Malgorzata PANKOWSKA (2021), Journal of Software \& Systems Development,

DOI: $10.5171 / 2021.668927$ 
market of SME clients. However, beyond that, the accountancy bureau is looking for opportunities for revenue increase by creating new services (or increasing the volume of services) targeted at its existing markets. The accountancy bureau has implemented service customisation. This organization does not consider the revenue increase through expanding into new markets, i.e., customer segments, geographic regions, countries. They are not interested in acquiring or merging with any other organization.

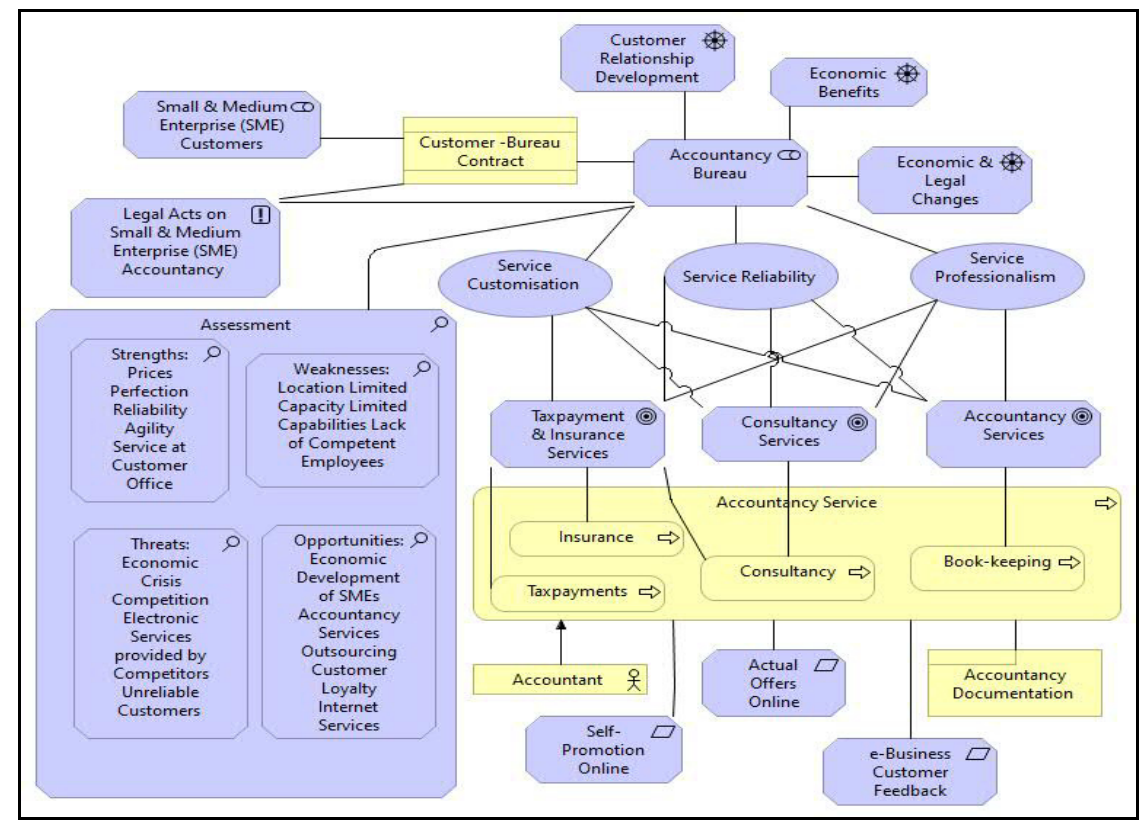

Fig. 3: Accountancy Bureau Architecture Motivation and Business Layer View in ArchiMate 3.1

Figure 3 includes Motivation and Business Layer View in ArchiMate language. This language is subordinate to the architectural semantics. In the EA modelling process, stakeholders focus on the following three issues:

- Business - ICT alignment context, i.e., the evolution of ICT systems to align them with business goals and business requirements (Figure 3);

- Context of strategic management of ICT, i.e., the implementation of a road map to transform business requirements into system requirements;

- Context of operating level management of the ICT systems.

The goal of business-driven ICT management is to determine mappings between business and technical requirements, and leverage these mappings to make ICT systems' management decisions that maximize business value metrics. These metrics are presented as key performance indicators (KPIs).

The OMG BMM is expected to specify the high-level business motivations as input into design, development and implementation of ICT systems. Even though the BMM integrates four primary motivational elements, i.e., ends, means, influencers and assessment, one may additionally consider checking if the tool supports pursuing answers to questions asked by Zachman, i.e., Why, Who, What, How, Where and When. Similarly as it is in ArchiMate language, the Assessment is a 
judgement of the impact of an Influencer on the Organization Unit. Assessment includes SWOT analysis and evaluates potential impacts in terms of Risks and Rewards (Figure 3 and 4). On the one hand, the Organizational Unit is able to recognize External and Internal Influencers, define Goals, identify the Strategy and conduct the SWOT analysis. On the other hand, the business Strategy determines the Organizational Unit, what is strictly according to Chandler's thesis.
The Strategy is formulated based on domain rules, i.e., SME Accounting Rules, and it is a component of the plan for the organization's Mission realization. The Organization Unit pursues the achievement of its Vision. Goals defined by the Organizational Units operationalize the business Vision. Realization of the business Strategy requires Business Policy as well as Means, which are understood as human, material and financial resources (Figure 4).

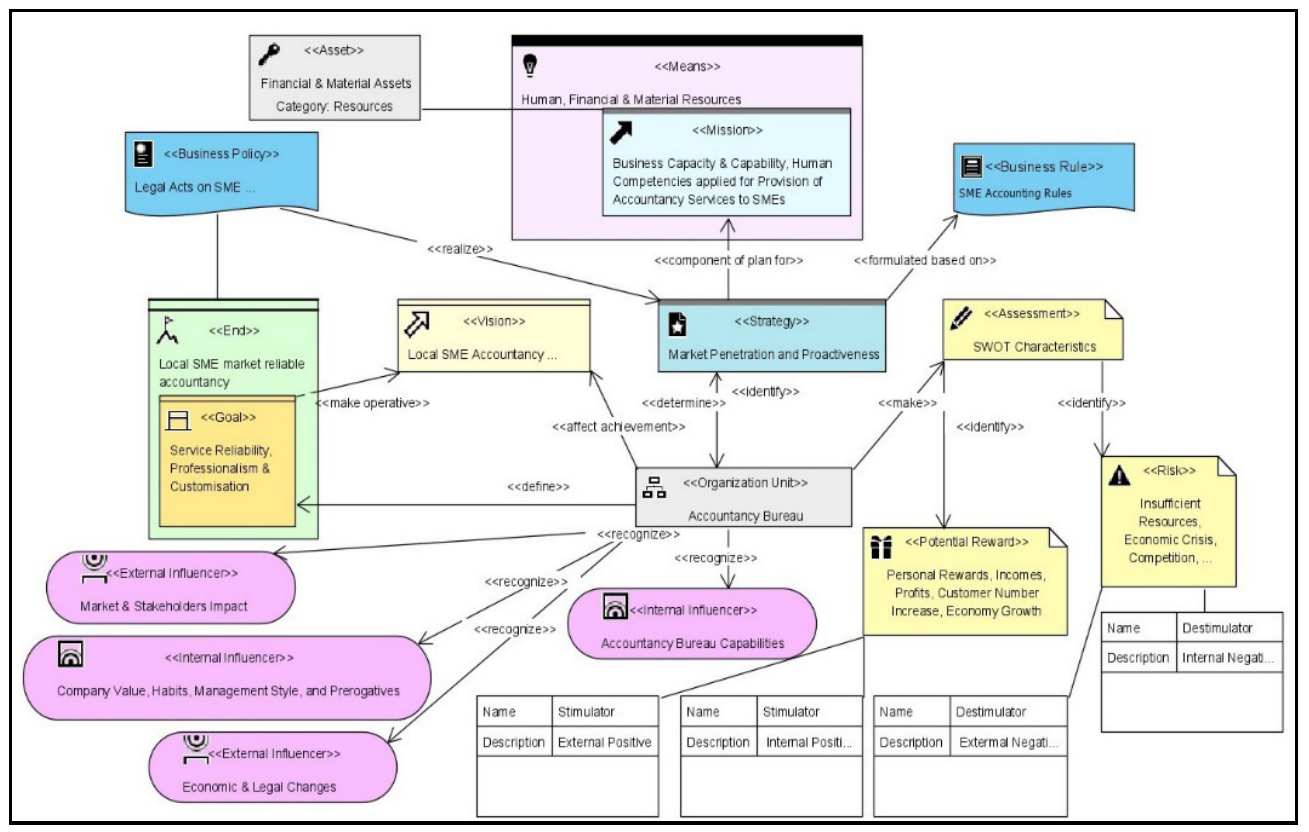

Fig. 4: SME Accountancy Bureau Business Motivation Model in Visual Paradigm 16.2

Regrettably, in comparison with the Zachman Framework, BMM does not contain a simple question of "Why". Nevertheless, the model concepts allow defining business rules, policy, strategy, mission, vision, assets, liabilities, offering, and even influencing organizations, so the model permits to better express an enterprise's governance and management than the models in ArchiMate. In the aspect of motivation, the concept of Value is needed, as it is defined in ArchiMate, because even the Goals and Objectives are not able to express the fundamental values. In fact, the Assessment and SWOT analysis are the basis for an enterprise evaluation in this model. A fundamental assumption of the BMM is that all enterprise activities are driven by how the enterprise decides to react to change. Therefore, in the BMM, the changes of economic phenomena are hidden in influencers, as they are included in the ArchiMate drivers. The long term reactions to changes are visible in trends of Key Performance Indicators (KPIs).

The recognition of changes caused by influencers and the assessment of their impact on the enterprise website design and e-business development are crucial. The problem is that BMM does not include a specific process on reaction to changes. The BMM is only to support the traceability of business processes, 
strategy, rules, means, goals, influencers and assessments. There is still the open question on the construction of KPIs. Usually, they concern fundamental economic metrics in a business organization, e.g., cost per sale, revenue, profit, customer satisfaction, margins, customer inquiries, invoice volume (Turban et al., 2011).

However, beyond that, there are indicators which concern specific aspects of enterprise functioning, e.g., safety and security, e-commerce, or business sustainability (Parisi and Maraghini, 2010). Generally, they are associated with a process and monitored in real time. Managers are interested in the implementation of KPIs, because organization performance always refers to how well business unit is working to reach its goals. Although there are several typical Google Analytics metrics, the business analyst's task is to specify an idiosyncratic set of metrics for enterprise performance evaluation. Proposed KPI list for the accountancy bureau is included in Table 3. The indicators concern only the analysed accountancy bureau and the transfer of these indicators to another enterprise should not be proposed. Monitoring the KPIs motivates the company managers to constantly reformulate business strategy and operations. Figure 5 presents the business strategy as decision dependent of uncertain and deterministic variables in ID diagram.

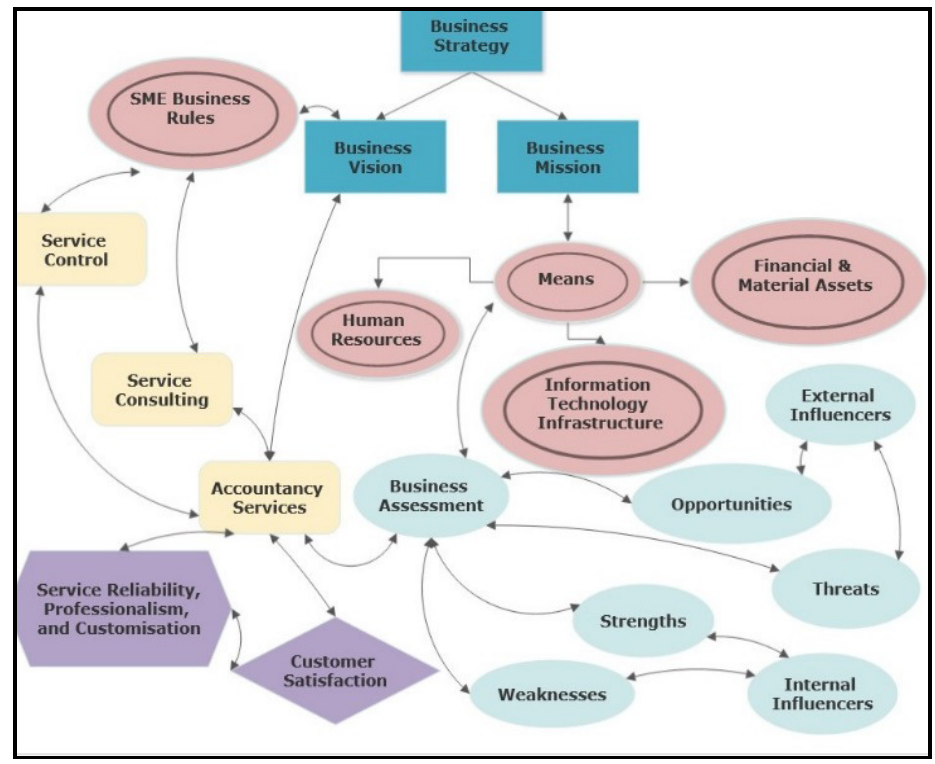

Fig. 5: Influence Diagram on SME Accountancy Bureau Motivation in SmartDraw Online

Table 3: Key Performance Indicators for Accountancy Bureau e-Business System

\begin{tabular}{|l|l|l|l|}
\hline Assessment & $\begin{array}{l}\text { External Negative } \\
\text { Impact }\end{array}$ & $\begin{array}{l}\text { Internal Negative } \\
\text { Impact }\end{array}$ \\
\hline $\begin{array}{l}\text { Imsers and New } \\
\text { Users }\end{array}$ & $\begin{array}{l}\text { Website Goal } \\
\text { Impact }\end{array}$ & Bounce Rate & High Cost per Sale \\
\hline Sessions & $\begin{array}{l}\text { Number of } \\
\text { Sessions/User }\end{array}$ & $\begin{array}{l}\text { User } \\
\text { different than Website }\end{array}$ & $\begin{array}{l}\text { Long Time of Order } \\
\text { Execution }\end{array}$ \\
\hline
\end{tabular}

Malgorzata PANKOWSKA (2021), Journal of Software \& Systems Development, 


\begin{tabular}{|c|c|c|c|}
\hline & & Language & \\
\hline $\begin{array}{l}\text { Average Session } \\
\text { Duration }\end{array}$ & $\begin{array}{ll}\text { Page } & \text { View } \\
\text { Browser } & \\
\end{array}$ & $\begin{array}{ll}\text { User } & \text { Geographic } \\
\text { Location } & \\
\end{array}$ & Amount of delay \\
\hline $\begin{array}{lr}\text { Percentage } & \text { of } \\
\text { New Sessions } & \end{array}$ & $\begin{array}{ll}\text { Sales } & \text { per } \\
\text { Download } & \\
\end{array}$ & $\begin{array}{l}\text { Business Rules } \\
\text { Changes in Year }\end{array}$ & $\begin{array}{l}\text { Lack of Competent } \\
\text { Employees }\end{array}$ \\
\hline Returning Users & Profit per Sale & Legislation Changes & $\begin{array}{l}\text { Lack of Knowledge } \\
\text { Management to deal with } \\
\text { Customer Requests }\end{array}$ \\
\hline $\begin{array}{l}\text { Frequency of } \\
\text { Sales }\end{array}$ & Revenue per Sale & Insurance & $\begin{array}{l}\text { Number of Questions per } \\
\text { Employee }\end{array}$ \\
\hline $\begin{array}{l}\text { Website Content } \\
\text { Downloads }\end{array}$ & $\begin{array}{l}\text { Customer } \\
\text { Satisfaction } \\
\end{array}$ & Tax Payment & $\begin{array}{l}\text { Number of Emails or } \\
\text { Phone Calls per Employee }\end{array}$ \\
\hline Valid Contacts & Profitability & Interest Rates & $\begin{array}{lll}\text { High } \quad \text { Complexity } & \text { of } \\
\text { Business Procedures } & \\
\end{array}$ \\
\hline Brand Image & Margins & Foreign Exchanges & $\begin{array}{l}\text { Long Process } \\
\text { Realization Duration }\end{array}$ \\
\hline Reputation & Investments & $\begin{array}{l}\text { Debt and Lease } \\
\text { Compliance }\end{array}$ & Process Changes \\
\hline \multirow[t]{4}{*}{$\begin{array}{l}\text { Customer } \\
\text { Inquiries } \\
\end{array}$} & Invoice Volume & Social Changes & Inefficient Cash Flow \\
\hline & & Staff Turnover & Credit-bad Debts \\
\hline & & Salary Inflation & $\begin{array}{l}\text { ICT Resources } \\
\text { Obsolescence }\end{array}$ \\
\hline & & Theft & $\begin{array}{lll}\text { Fraud and } & \text { Resource } \\
\text { Misuse } & & \\
\end{array}$ \\
\hline
\end{tabular}

\section{Conclusions}

Noting that a large volume of publications on work motivations exists, authors focus and justify mostly individual motivations, although there are journal papers and books on business organization motivations as a separate issue. However, there are still too few publications on the EA development motivations as well as on motivations for any computer application implementation and deployment. Motivation analysis should not be omitted. In motivation models, the focus should be on drivers, influencers, motivators stimulating or discouraging to act. In this paper, case study has been presented and three different notations have been applied to emphasize the motivation of information system development. Proposed KPIs allow for an assessment of the Influencers' impact and they are connected with the business strategy. In this paper, the Business Motivation analysis has been considered on the strategic level of system analysis. As such it is highly recommended for system analysts and developers, who provide the information system development justification.

\section{References}

- ArchiMate 3.1 Specification, The Open Group (2019). [Online], [Retrieved March 17, 2020], https://publications.opengroup.org /downloadable/customer/products L

- BABOK, Guide 3, A Guide to the Business Analysis Body of Knowledge (2015), International Institute of Business Analysis, Toronto.

- Badubi, R.M. (2017), "Theories of Motivation and Their Application in Organizations: A Risk Analysis," International Journal of Innovation and Economic Development. Volume 3, Issue 3, August 2017, 44-51

- Berkem, B. (2008), "From the business motivation model to Service Oriented Architecture (SOA)," Journal of Object Technology, 7(8), 57-70

- Bhattacharya, P.(2018), Synthesis of

Malgorzata PANKOWSKA (2021), Journal of Software \& Systems Development, 
Business Motivation Model (BMM) and ArchiMate: Towards a New Modelling Technique for Strategic Alignment of Business and IT. MCIS Proceesings, [Online], [Retrieved March 20, 2020], https://aisel.aisnet.org/cgi/mcis201 $\underline{8}$

- $\quad$ Bridgeland, D.M., Zahavi, R. (2009) Business Modeling: A Practical Guide to Realizing Business Value. Morgan Kauffman, Elsevier, Amsterdam.

- Chandler, A.D.(1962), Strategy and Structure, MIT Press, Cambridge, MA.

- $\quad$ Cui, X., Paige, R. (2012), An Integrated Framework for System/Software Requirements Development Aligning with Business Motivations, IEEE 11th International Conference on Computer and Information Science, ISBN: 978-07695-4694-0/12, May 30, 2012 to June 1, 2012, Shanghai, China, 547552

- EABOK, Guide to the (Evolving) Enterprise Architecture Body of Knowledge (2004), [Online], [Retrieved March 13, 2020], https://www.mitre.org/sites/defaul t/files/pdf/04_0104.pdf

- FEAF, The Common Approach to Federal Enterprise Architecture (2012), [Online], [Retrieved March 13, 2020], https://obamawhitehouse.archives. gov/sites/default/files/omb/assets Legov docs/common approach to $\mathrm{f}$ ederal ea.pdf

- Feglar, T., Jason, K.L., Feglar, T., Feglar, T. Jr. (2006), "Advances in decision analysis and systems engineering for managing largescale enterprises in a volatile world: Integrating Benefits, Opportunities, Costs and Risks (BOCR) with the Business Motivation Model (BMM)," Journal of Systems Science and Systems Engineering, Vol 15 Issue 2, 141-153

- Gaque, M.F., Haque, M.A., Islam, M.S. (2014), "Motivational Theories - A Critical Analysis." ASA University Review. Vol.8., No 1., January-June, [Online], [Retrieved January 15,
2020], https://www.researchgate.net/publ ication/306255973

- Hall, W.L. (2010), Constructing a Decision Model, Sustainable Land Development and Restoration, Decision Consequence Analysis, 111-136, Brown K., Hall W.L, Snook M., Garvin K. (eds.), Butterworth Heinemann, Amsterdam.

- Hoogervorst, J.A.P.(2009), Enterprise Governance and Enterprise Engineering, Springer, Berlin.

- Hinkelmann, K., Pasquini, A.(2014), "Supporting Business and IT Alignment by Modeling Business and IT Strategy and Its Relations to Enterprise Architecture," IEEE Computer Society, Second International Conference on Enterprise Systems, ISBN: 978-14799-5554-1/14, August 2-3, Shanghai, China, 149-154

- Lu, Q., Tosic, V., Bannerman, P.L. (2011), Support for the business motivation model in the WSPolicy4MASC language and MiniZnMASC middleware, ServiceOriented Computing, ICSOC 2011, 7084 LNCS, 265-279, Kappel G., Maamar Z., Motahari-Nezhad H.R. (eds.) Springer, Berlin.

- OMG, Object Management Group, Business Motivation Model, Version 1.3 (2015). [Online], [Retrieved March 17, 2020], http://www.omg.org/spec/BMM/1. 3/

- Parisi, C., Maraghini, M.P. (2010), Operationalising Sustainability: How Small and Medium Sized Enterprises Translate Social and Environmental Issues into Practice, Business Performance Measurement and Management, New Contexts, Themes and Challenges, 131-148, Taticchi P. (ed), Springer-Verlag, Berlin.

- Rheinberg, F.(2008), Motivation, Kohlhammer, Stuttgart.

- Roubtsova, E. (2012), “Business process and motivation of objectives in one model," BMSD 2012 Proceedings of the 2nd International Symposium on Business Modeling 
and Software Design, ISBN: 978989-8565-26-6, July 4-6, Geneva, Switzerland, 24-32.

- Stair, R., Reynolds G. (2010), Principles of Information Systems, Course Technology, Cengage Learning, Walldorf .

- $\quad$ Stenzel, J. (2007), CIO Best Practices Enabling Strategic Value with Information Technology, John Wiley \& Sons, Hoboken.

- Suri, K., Cadavid, J., Alferez, M., Dhouib, S., Tucci-Piergiovanni, S. (2017), "Modeling business motivation and underlying processes for RAMI 4.0-Aligned Cyber-physical Production Systems," 22nd IEEE International Conference on Emerging Technologies and Factory Automation (EFTA), ISBN: 978-1-5090-6505-9, September 1215, Limassol, Cyprus, 1-6.

- Tonisson, R., Matulevicius, R. (2016), A Coarse-Grained Comparison of Modelling Languages for Business
Motivation and Intentional Distribution, Perspectives in Business Informatics Research, 8095, Repa V., Bruckner T. (eds.), Springer, Heidelberg.

- Turban, E., Volonino, L., Sipior, J.C., Wood, G.R. (2011), Information Technology for Management, Improving Strategic and Operational Performance. John Wiley \& Sons, Hoboken.

- Vicente, M., Gama, N., Da Silva, M.M.(2014), "A business motivation model for IT service management," International Journal of Information System Modeling and Design. 5(1), 83-107.

- Zachman, J.A. (2010), Frameworks Standards: What's It All About? The SIM Guide to Enterprise Architecture, 66-70, Kappelman L.A. (ed), CRC Press, Boca Raton. 